\title{
An Analysis of the Informational Value of Sovereign Credit Ratings
}

\author{
Kok-Tiong Lim ${ }^{\mathrm{a}}$ \\ Kian-Teng Kwek \\ University of Malaya
}

\begin{abstract}
The sovereign credit ratings (SCRs) have been an integral part in the global financial system in asset allocation and price discovery. The zero bound policy rate (ZBPR) and quantitative easing programme (QEP) rolled out by the four key central banks as antidotes to the global financial crisis (GFC) would have altered the assumed premise on SCRs relevancy. This preliminary study is crafted for a validation on whether the SCRs informational value on sovereign bond yields (SBYs) and sovereign credit default swap spreads (SCDSSs) was indeed affected when ZBPR and QEP were in effect. A sample of 32 countries with observations spanning from 2008 to 2017 to encompass the period of ZBPR and QEP in effect was used for analysis. The empirical results show that SCRs informational value was indeed rendered irrelevant on $S B Y_{S}$ price discovery since 2008 and the effect on SCDSSs came in later from 2012 onwards.
\end{abstract}

Keywords: Quantitative easing programme, sovereign credit ratings, sovereign bond yields, sovereign credit default swap spreads, zero bound policy rate

JEL classification: C23, F34, G01, G15, G24

\section{Introduction}

It has been a common affair for policymakers to draw support on their economic policies from credit rating agencies (CRAs) when the assigned sovereign credit ratings (SCRs) were maintained or upgraded, or to discredit the CRAs who downgraded the assigned SCRs. In fact, a "Pulitzer Price" winner columnist had warned about the influence of CRAs to be at par with the US government through the upgrading and downgrading of SCRs (Friedman, 1996). Despite his highly publicised warning, the number of rated countries doubled to 142 in 2016. According to the NRSRO 2016 report, ${ }^{1} 99 \%$ of government debts were rated by Moody's, S\&P and Fitch.

The alphanumeric SCRs (i.e., Aaa, Aa1, Aa2, Aa3, etc.) issued by Moody's and the alpha-symbol SCRs (i.e., AAA, AA+, AA, AA-, etc.) issued by S\&P and Fitch are tagging used to rank the creditworthiness of rated countries. For instance, countries rated

a Faculty of Economics \& Administration, University of Malaya, 50603 Kuala Lumpur, Malaysia. Email: kttlim@siswa.um.edu.my or kttlim@yahoo.com

b Faculty of Economics \& Administration, University of Malaya, 50603 Kuala Lumpur, Malaysia. Email: ktkwek@um.edu.my (Corresponding Author)

1 Based on annual report of nationally recognised statistical rating organisations (NRSRO) dated December 2016 from US Securities and Exchange Commission.

Article Info: Received 20 June 2019; Revised 5 October 2020; Accepted 17 March 2021 https://doi.org/10.22452/MJES.vol58no1.5 
Aaa/AAA are defined as having the highest creditworthiness and hence enjoy the lowest borrowing cost. Countries rated $A a 1 / A A+$ are considered inferior to those rated with Aaa/AAA but superior to those rated with Aa2/AA, and so on. In other words, the alphanumeric/alpha-symbol SCRs convey informational value on price discovery, especially on sovereign bond yields.

The zero bound policy rate (ZBPR) and quantitative easing programme (QEP) that rolled out in 2018 as measures to mitigate the impact of global financial crisis could have an impact on the SCRs informational value. Since SCRs are fully integrated into the global financial system, the question on the SCRs and SCRs informational value relevancy is a worthy research subject.

This paper examines the conjecture regarding the effect of ZBPR and QEP on SCRs informational value on sovereign bond yields (SBYS) and sovereign credit default swap spreads (SCDSSs) price discoveries. Panel model estimates using a sample of 32 countries with observations spanning from 2008 to 2017 collected in quarterly intervals produced mixed empirical results regarding SCRs informational value relevancy. After accounting for country specific effect, the SCRs informational value indeed rendered irrelevant on SBYS price discovery while ZBPR and QEP were in effect. On the other hand, the estimates on SCDSSS show that SCRs informational value were also rendered irrelevant on SCDSSS price discovery. However, the effect of ZBPR and QEP on SCDSSS only set in from 2012 onwards.

The remaining of this paper is organised as follows. A summarised literature review is presented in Section 2, and this is followed by Section 3 that describes the data. The models selected for this empirical study are elaborated in Section 4. In Sections 5 and 6, the empirical estimates and the discussion on the empirical findings will be presented and shared, respectively. Finally, the conclusion is presented in Section 7.

\section{Literature Review}

Literature regarding credit ratings could be found published since the 1980 s but mainly on corporate ratings (Ederington, 1986; Ederington et al., 1987). The sovereign credit rating (SCRs) probably caught the attention of researchers in the 1990s (Cantor \& Packer, 1994, 1995, 1996; Cantor et al., 1997).

In particular to the sovereign credit ratings, one of the most cited and earliest research was the work of Cantor and Packer (1996). Their research approach and coverage mirrored the same approach adopted by Ederington et al. (1987), focusing on the determinants of SCRs than the informational value of SCRs on sovereign bond yields $(S B Y S)$ price discovery. The financial variables in corporate ratings were substituted with economic variables cited from the credit rating agencies as causes of SCRs upgrades and downgrades. The empirical results were commendable where the selected economic variables had over $90 \%$ explanatory power on both the actual SCRs and SBYS price discovery. In subsequent studies, most researchers approach the SCRs determinants and SCRs informational value as two separate themes.

Building on the work of Cantor and Packer (1996) on SCRs determinants, the work of Afonso (2003) expanded the base of rated countries to 81 and introduced additional economic variables as potential SCRs determinants. The work of Rowland 
(2004) focused on examining new economic variables as potential determinants. Then came the breakthrough, the flaw of using cross-sectional method on the discreet characteristic of SCRs as highlighted by Wooldridge (2002) caught the attention. The research emphasis on SCRs determinant was broadened to include the regression method. The work of Bissoondoyal-Bheenick (2005) was probably the first to adopt the ordered probit model to study SCRs determinants. The ordered logit model was adopted by Mellios and Paget-Blanc (2006) in a similar study. Both ordered response models were adopted by Afonso et al. (2009) to examine a set of 24 potential determinants of SCRs. In a separate paper, Afonso et al. (2011) reclassified the set of potential determinants into short-term and long-term determinants. In a more recent paper, Reusens and Croux (2017) examined the significance of specific determinants of SCRs in relation to European countries.

On the theme of SCRs informational value, there are many more variations. These include: (a) the studies on the "above and beyond" information of SCRs informational value on SBYs (Afonso et al., 2013; Miricescu, 2015; Jaramillo \& Tejada, 2011; Jaramillo \& Weber, 2013; Sy, 2002), (b) earlier studies using SCRs as proxy of credit risk component on sovereign credit default swap spreads (SCDSSs) (Badaoui et al., 2013; Beber et al., 2009; Culp et al., 2016; Hull \& White, 2000; Longstaff et al., 2011), and (c) the study on causality on split-SCRs amongst the CRAs (Alsakka \& Gwilym, 2010a, 2010b).

In summary, there is no study emphasising the effect of ZBPR and QEP on SCRs determination nor SCRs informational value on SBYS or SCDSSs. The literature that contains some emphasis relating to ZBPR and QEP we could relate to is the work of Reusens and Croux (2017), but the findings were predominantly on European countries and not the SCRs. For this study, the focus is on the SCRs informational value research gap. The objective of this study is to determine whether the SCRs informational value were indeed rendered irrelevant on SBYS and SCDSSs price discovery when ZBPR and QEP were in effect.

\section{Data}

The sample consists of 32 countries with observations spanning from 2008 to 2017 to reflect the entire period that ZBPR and QEP were effective. These 32 countries are selected because all are multi-rated by Moody's, S\&P and Fitch, and with sovereign bond yields (SBYs) and sovereign credit default swap spreads (SCDSSs) tracked on Bloomberg. The list of 32 selected countries is presented in Table 1. The SCRs issued by these three CRAs are sourced from Bloomberg where quarterly data points following the same observation window are gathered. These SCRs were converted into ordinal scale following the similar convention adopted by earlier studies (Afonso et al., 2011; Bissoondoyal-Bheenick, 2005; Cantor \& Packer, 1996; Canuto et al., 2012; Hill et al., 2010; Mellios \& Paget-Blanc, 2006; Reusens \& Croux, 2017) as defined in Table 2.

The $S B Y$ S are selected as dependent variables because the SCRs are directly related to $S B Y S$. Therefore, it is only logical to study SCRs informational value on SBYS. Since the SCDSSS are derivatives of $S B Y S$ and $S B Y S$ being the reference entity (Culp et al., 2016), the SCRs informational value study could also be extended to SCDSSs. Both SBYS and SCDSSS with 5-year maturity are sourced from Bloomberg. This is to 
Table 1. List of 32 selected countries

\begin{tabular}{llll}
\hline Australia & Finland & Lithuania & Slovenia \\
Austria & France & Malaysia & South Korea \\
Belgium & Germany & Mexico & Spain \\
Bulgaria & Hong Kong & Netherlands & Sweden \\
Chile & Ireland & Norway & Switzerland \\
China & Israel & New Zealand & Thailand \\
Czech & Italy & Poland & United Kingdom \\
Denmark & Japan & Slovakia & United States \\
\hline
\end{tabular}

Note: The list of cross-sectional sovereigns is based on data availability (i.e., SBY, SCDSS and SCRs from the three leading CRAs from two sources, i.e., Bloomberg and Thomson Reuters).

Table 2. Harmonised SCRs and SCRs ordinal scales

\begin{tabular}{|c|c|c|c|c|}
\hline Description & Moody's & $S \& P$ & Fitch & Ordinal scale \\
\hline \multicolumn{5}{|l|}{ Investment grade } \\
\hline Highest credit quality & Aaa & AAA & AAA & 21 \\
\hline \multirow[t]{3}{*}{ High credit quality } & Aa1 & $\mathrm{AA}+$ & $\mathrm{AA}+$ & 20 \\
\hline & $\mathrm{Aa} 2$ & $\mathrm{AA}$ & $\mathrm{AA}$ & 19 \\
\hline & Aa3 & AA- & $A A-$ & 18 \\
\hline \multirow[t]{3}{*}{ Strong payment capacity } & A1 & $A+$ & $A+$ & 17 \\
\hline & $\mathrm{A} 2$ & $A$ & $A$ & 16 \\
\hline & A3 & $A-$ & A- & 15 \\
\hline \multirow[t]{3}{*}{ Adequate payment capacity } & Baa1 & $\mathrm{BBB}+$ & $\mathrm{BBB}+$ & 14 \\
\hline & Baa2 & BBB & BBB & 13 \\
\hline & Baa3 & BBB- & BBB- & 12 \\
\hline \multicolumn{5}{|l|}{ Speculative grade } \\
\hline \multirow[t]{3}{*}{ Likely to fulfil obligation } & Ba1 & $\mathrm{BB}+$ & $\mathrm{BB}+$ & 11 \\
\hline & $\mathrm{Ba} 2$ & BB & BB & 10 \\
\hline & Ba3 & BB- & BB- & 9 \\
\hline \multirow[t]{3}{*}{ High credit risk } & B1 & $\mathrm{B}+$ & $\mathrm{B}+$ & 8 \\
\hline & B2 & B & $B$ & 7 \\
\hline & B3 & $B-$ & B- & 6 \\
\hline \multirow[t]{3}{*}{ Very high credit risk } & Caa1 & $\mathrm{CCC}+$ & $\mathrm{CCC}+$ & 5 \\
\hline & Caa2 & $\mathrm{CCC}$ & $\mathrm{CCC}$ & 4 \\
\hline & Caa3 & CCC- & $\mathrm{CCC}-$ & 3 \\
\hline \multirow[t]{2}{*}{ Near default } & $\mathrm{Ca}$ & $\mathrm{CC}$ & $\mathrm{CC}$ & 2 \\
\hline & C & & C & 1 \\
\hline \multirow[t]{3}{*}{ Default } & & SD & DDD & 0 \\
\hline & & $\mathrm{D}$ & DD & \\
\hline & & & $\mathrm{D}$ & \\
\hline
\end{tabular}

Note: The exact description could be slightly different when referring to specific SCR methodology, but the underlying risk profile could be harmonised and converted to ordinal scale as defined above. Moody's does not provide rating on defaulted countries.

Source: Bloomberg. 
ensure that the efficient market theory (Fama, 1969) is observed to some extent. Since heteroscedasticity issue is common with cross-sectional data, both SBYS and SCDSSS are converted to logarithmic form in similar fashion as adopted in earlier studies (Cantor \& Packer, 1996; Ederington et al., 1987; Miricescu, 2015). For SBYs, the logarithmic conversion will take the value of base plus 2 to address the negative value. The descriptive statistics of all selected variables are presented in Table 3 . The sample is reclassified into a full sample that constitutes observations from Q1 2008 to Q4 2017, and annual datasets by year.

Table 3. Descriptive statistics

\begin{tabular}{lrrrrrrr}
\hline & $\begin{array}{l}\text { Moody's } \\
\text { SCR }\end{array}$ & $\begin{array}{r}\text { S\&P } \\
\text { SCR }\end{array}$ & $\begin{array}{c}\text { Fitch } \\
\text { SCR }\end{array}$ & SBYs & $\begin{array}{c}\text { Log } \\
\text { SBYs+2 }\end{array}$ & SCDSSs & $\begin{array}{c}\text { Log } \\
\text { Mean }\end{array}$ \\
\hline Median & 17.991 & 18.016 & 17.959 & 2.167 & 0.579 & 93.360 & 4.199 \\
Maximum & 19.000 & 19.000 & 19.000 & 2.005 & 0.603 & 68.290 & 4.224 \\
Minimum & 21.000 & 21.000 & 21.000 & 12.673 & 1.167 & 753.950 & 6.625 \\
Std. dev. & 12.000 & 11.000 & 12.000 & -0.920 & 0.033 & 7.000 & 1.946 \\
Skewness & 2.856 & 2.869 & 2.876 & 1.776 & 0.194 & 90.171 & 0.816 \\
Kurtosis & -0.471 & -0.527 & -0.423 & 0.652 & -0.241 & 2.903 & 0.118 \\
\hline Observations & 1.859 & 2.002 & 1.820 & 3.688 & 2.215 & 15.123 & 2.702 \\
\hline
\end{tabular}

Note: The sample consists of 32 countries with observation window spanning Q1 2008 to Q4 2017, sourced from Bloomberg and Thomson Reuters. The variables with complete information have 1280 observations. Due to missing data points from SBYS and SCDSSs, the total observations are lesser as reported.

\section{Methodology}

For the purpose of this preliminary study, the regression model from the work of Cantor and Packer (1996) is adopted and modified to suit the panel data setup of this study. The modified panel regression model is expressed in equation 1.

$$
y_{i t}=\alpha+\beta x_{i t}+v_{i t}
$$

where $y_{i}$ represents the sovereign bond yields (SBYs) or sovereign credit default swap spreads (SCDSSs) of selected countries denoted by $i$ at time $t, \alpha$ is the common intercept, $x_{i t}$ denotes the SCRs of Moody's, S\&P, and Fitch, $\beta$ is the coefficient, and $v_{i t}$ denotes the composite error term.

Besides the pooled OLS model as expressed in Equation 1, the panel fixed effect and panel random effect models were also estimated to address the country specific factor and unobserved factor, respectively. Both Hausman test and Wald test were conducted to determine the appropriate model. All the three panel models and test models were estimated using the full sample and annual datasets. The estimations were repeated on SCRs of the three respective CRAs.

For SCRs informational value to be relevant in explaining SBYS and SCDSSs, the estimated coefficients of SCRs must be significant and with the expected negative 
sign. The $5 \%$ significance level is used. The expected negative sign is based on the riskreward pricing convention, where higher risk leads to higher expected returns or cost of borrowing. Since SCR notches are proxies on default risk of the rated countries and the ordinal scale conversion convention defined in Table 2, the expected sign on the estimated coefficient of SCRs is negative. With these two assessment criteria, the SCRs informational value on debts pricing could therefore be determined.

\section{Empirical Estimates}

Empirical estimates derived from the full sample using pooled OLS, panel fixed effect $(\mathrm{FE})$, and panel random effect (RE) are presented in Table 4. The granular estimates derived from annual datasets using the panel FE model are compiled in Table 5.

From the full sample, pooled OLS estimated coefficients are all significant at $5 \%$ level and with the expected negative sign in explaining SBYs. All the panel FE estimated coefficients are also significant at $5 \%$ level, but are without the negative sign as

Table 4. Estimates from full sample

\begin{tabular}{|c|c|c|c|c|c|c|}
\hline & \multicolumn{3}{|c|}{ Log SBYs2 } & \multicolumn{3}{|c|}{ Log SCDSSS } \\
\hline & $\begin{array}{l}\text { Moody's } \\
\text { SCRs }\end{array}$ & $\begin{array}{l}\text { S\&P } \\
\text { SCRS }\end{array}$ & $\begin{array}{l}\text { Fitch } \\
\text { SCRs }\end{array}$ & $\begin{array}{l}\text { Moody's } \\
\text { SCRs }\end{array}$ & $\begin{array}{l}\text { S\&P } \\
\text { SCRS }\end{array}$ & $\begin{array}{l}\text { Fitch } \\
\text { SCRs }\end{array}$ \\
\hline \multicolumn{7}{|c|}{ Pooled OLS (POLS) Model } \\
\hline Coef. & -0.016 & -0.021 & -0.021 & -0.178 & -0.189 & -0.188 \\
\hline Std. error & 0.002 & 0.002 & 0.002 & 0.006 & 0.006 & 0.006 \\
\hline$p$-value & 0.000 & 0.000 & 0.000 & 0.000 & 0.000 & 0.000 \\
\hline Adj. $R^{2}$ & 0.062 & 0.095 & 0.096 & 0.430 & 0.443 & 0.439 \\
\hline \multicolumn{7}{|c|}{ Fixed Effect (FE) Model } \\
\hline Coef. & 0.024 & 0.031 & 0.035 & -0.042 & -0.052 & -0.031 \\
\hline Std. error & 0.003 & 0.004 & 0.004 & 0.012 & 0.015 & 0.016 \\
\hline$p$-value & 0.000 & 0.000 & 0.000 & 0.001 & 0.001 & 0.046 \\
\hline Adj. $R^{2}$ & 0.482 & 0.485 & 0.489 & 0.542 & 0.542 & 0.539 \\
\hline \multicolumn{7}{|c|}{ Random Effect (RE) Model } \\
\hline Coef. & 0.016 & 0.017 & 0.019 & -0.113 & -0.131 & -0.127 \\
\hline Std. error & 0.003 & 0.004 & 0.004 & 0.009 & 0.011 & 0.011 \\
\hline$p$-value & 0.000 & 0.000 & 0.000 & 0.000 & 0.000 & 0.000 \\
\hline Adj. $R^{2}$ & 0.020 & 0.017 & 0.020 & 0.103 & 0.099 & 0.096 \\
\hline \multicolumn{7}{|c|}{ Hausman Test } \\
\hline Chi-square & 31.400 & 46.543 & 52.612 & 82.582 & 50.862 & 68.316 \\
\hline$p$-value & 0.000 & 0.000 & 0.000 & 0.000 & 0.000 & 0.000 \\
\hline \multicolumn{7}{|l|}{ Wald Test } \\
\hline F-statistic & 47.060 & 54.002 & 63.019 & 522.742 & 339.799 & 283.298 \\
\hline$p$-value & 0.000 & 0.000 & 0.000 & 0.000 & 0.000 & 0.000 \\
\hline
\end{tabular}

Note: Coef. $=$ Coefficient, Std. error $=$ Standard error. The estimates are generated on the full dataset constituting observations from Q1 2008 to Q4 2017 of 32 countries listed in Table 1. 
Table 5. Panel FE estimates from annual datasets

\begin{tabular}{|c|c|c|c|c|c|c|c|}
\hline & & & og SBYS & & & S SCDS & \\
\hline & & $\begin{array}{l}\text { Moody's } \\
\text { SCRs }\end{array}$ & $\begin{array}{l}\text { S\&P } \\
\text { SCRs }\end{array}$ & $\begin{array}{l}\text { Fitch } \\
\text { SCRs }\end{array}$ & $\begin{array}{l}\text { Moody's } \\
\text { SCRs }\end{array}$ & $\begin{array}{l}\text { S\&P } \\
\text { SCRs }\end{array}$ & $\begin{array}{l}\text { Fitch } \\
\text { SCRs }\end{array}$ \\
\hline 2008 & Coef. & & -0.071 & -0.020 & 0.370 & 0.263 & 0.061 \\
\hline & Std. error & & 0.043 & 0.054 & 0.827 & 0.402 & 0.542 \\
\hline & p-value & & 0.106 & 0.708 & 0.656 & 0.515 & 0.910 \\
\hline & Adj. $R^{2}$ & & 0.619 & 0.592 & 0.509 & 0.510 & 0.508 \\
\hline 2009 & Coef. & 0.032 & 0.039 & 0.003 & 0.322 & 0.323 & 0.267 \\
\hline & Std. error & 0.013 & 0.015 & 0.014 & 0.219 & 0.226 & 0.191 \\
\hline & p-value & 0.016 & 0.011 & 0.838 & 0.145 & 0.157 & 0.166 \\
\hline & Adj. $R^{2}$ & 0.944 & 0.944 & 0.939 & 0.627 & 0.627 & 0.626 \\
\hline 2010 & Coef. & 0.002 & -0.022 & -0.011 & -0.156 & -0.359 & -0.223 \\
\hline & Std. error & 0.017 & 0.018 & 0.022 & 0.043 & 0.071 & 0.061 \\
\hline & p-value & 0.884 & 0.214 & 0.611 & 0.001 & 0.000 & 0.001 \\
\hline & Adj. $R^{2}$ & 0.927 & 0.928 & 0.927 & 0.881 & 0.893 & 0.881 \\
\hline 2011 & Coef. & 0.003 & -0.013 & 0.008 & -0.216 & -0.123 & -0.305 \\
\hline & Std. error & 0.013 & 0.020 & 0.029 & 0.091 & 0.141 & 0.205 \\
\hline & p-value & 0.838 & 0.521 & 0.777 & 0.019 & 0.385 & 0.141 \\
\hline & Adj. $R^{2}$ & 0.830 & 0.830 & 0.830 & 0.676 & 0.659 & 0.664 \\
\hline 2012 & Coef. & 0.004 & 0.005 & -0.009 & 0.055 & 0.063 & 0.009 \\
\hline & Std. error & 0.011 & 0.014 & 0.015 & 0.073 & 0.096 & 0.099 \\
\hline & p-value & 0.717 & 0.752 & 0.533 & 0.449 & 0.512 & 0.928 \\
\hline & Adj. $R^{2}$ & 0.933 & 0.910 & 0.910 & 0.795 & 0.794 & 0.793 \\
\hline 2013 & Coef. & 0.010 & -0.015 & -0.021 & 0.115 & 0.364 & 0.195 \\
\hline & Std. error & 0.020 & 0.029 & 0.018 & 0.106 & 0.146 & 0.090 \\
\hline & p-value & 0.607 & 0.604 & 0.228 & 0.281 & 0.014 & 0.033 \\
\hline & Adj. $R^{2}$ & 0.941 & 0.941 & 0.942 & 0.936 & 0.940 & 0.939 \\
\hline 2014 & Coef. & -0.034 & -0.019 & -0.055 & -0.188 & -0.169 & -0.174 \\
\hline & Std. error & 0.023 & 0.016 & 0.027 & 0.063 & 0.043 & 0.076 \\
\hline & p-value & 0.138 & 0.229 & 0.043 & 0.004 & 0.000 & 0.024 \\
\hline & Adj. $R^{2}$ & 0.904 & 0.903 & 0.906 & 0.959 & 0.961 & 0.957 \\
\hline 2015 & Coef. & 0.031 & -0.010 & 0.014 & 0.101 & -0.044 & -0.314 \\
\hline & Std. error & 0.020 & 0.014 & 0.036 & 0.092 & 0.064 & 0.167 \\
\hline & p-value & 0.114 & 0.484 & 0.708 & 0.276 & 0.492 & 0.063 \\
\hline & Adj. $R^{2}$ & 0.968 & 0.967 & 0.967 & 0.965 & 0.964 & 0.965 \\
\hline 2016 & Coef. & 0.039 & 0.035 & 0.047 & 0.018 & -0.044 & 0.083 \\
\hline & Std. error & 0.024 & 0.017 & 0.022 & 0.092 & 0.063 & 0.076 \\
\hline & p-value & 0.107 & 0.043 & 0.038 & 0.847 & 0.493 & 0.278 \\
\hline & Adj. $R^{2}$ & 0.971 & 0.972 & 0.972 & 0.952 & 0.952 & 0.952 \\
\hline 2017 & Coef. & -0.023 & -0.032 & -0.004 & -0.040 & 0.042 & 0.000 \\
\hline & Std. error & 0.008 & 0.010 & 0.013 & 0.075 & 0.090 & 0.114 \\
\hline & p-value & 0.003 & 0.001 & 0.728 & 0.593 & 0.639 & 1.000 \\
\hline & $\operatorname{Adj} . R^{2}$ & 0.989 & 0.989 & 0.988 & 0.901 & 0.901 & 0.901 \\
\hline
\end{tabular}

Note: Coef. $=$ Coefficient, Std. error $=$ Standard error. The estimates are generated on the full dataset constituting observations from Q1 2008 to Q4 2017 of 32 countries. For Moody's SCRs on 2008 annual dataset, the regression cannot be estimated due to near singularity problem. 
expected. The SCRs coefficients with positive sign are counter-intuitive because the riskreward pricing convention is violated. The same outcome can be observed from all the panel RE estimated coefficients. Since the Hausman test's null hypothesis on the panel RE model being the appropriate model is rejected, and the Wald test has concurred that panel FE model is better fitted, the discussion in the following section will be based on panel FE estimates. On the SCDSSs estimates, the estimated coefficients of SCRs issued by all three leading CRAs are significant at $5 \%$ level and with the expected negative sign. The results are consistent and unanimous on estimates generated from pooled OLS, panel FE and panel RE models. The Hausman and Wald tests concurred that panel FE model is the appropriate model, therefore the discussion in the following section will rely on panel FE estimates.

On the granular estimates derived from annual datasets using panel FE model as compiled in Table 5, all the estimated coefficients in explaining $S B Y$ s are either significant at $5 \%$ level but with positive sign or insignificant at 5\% level but with the expected negative sign. Only estimates from the 2017 dataset are significant at $5 \%$ level and with the expected negative sign. With regards to SCDSSs, the granular estimates are rather dynamic. Only estimates from the annual dataset of year 2010 and 2014 are significant at $5 \%$ level and with the expected negative sign on SCRs issued by all three leading CRAs. For year 2011, only the SCRs issued by Moody's are significant at $5 \%$ level and with the expected negative sign. For year 2015, the SCRs issued by Fitch are significant at $10 \%$ level and with the expected negative sign. On the remaining estimates, they are either significant with positive sign or insignificant with negative sign. Both granular estimates on SBYS and SCDSSS are discussed in the following section.

\section{Discussion}

The results from Table 4 provide an overview of SCRs informational value on SBYS price discovery when ZBPR and QEP were in effect. The results are unanimous on SCRs issued by all three CRAs that SCRs informational value was disregarded in pricing of $S B Y$ S during those periods. With the granular estimates as summarised in Table 6 , annual estimates clearly show that SBYS disregarded SCRs informational value, irrespective of CRAs, on price discovery from 2008 to 2017. There are exceptions observed in year 2014 on SCRs issued by Fitch which is significant at $5 \%$ level and with the negative sign, and also in year 2017 on SCRs issued by Moody's and S\&P which are significant at $5 \%$ level and with the expected negative sign. Since no granular estimates from the annual datasets show concurring results from all three CRAs, this further supports the results derived from the full sample as empirical evidence that the SCRs informational value were indeed rendered irrelevant on $S B Y S$ price discovery when ZBPR and QEP were in effect.

The effect of ZBPR and QEP that rendered SCRs informational value irrelevant on $S B Y S$ price discovery could be visually observed from the line chart depicted in Figure 1. In 2008, the average SCRs issued by respective CRAs was at the ordinal scale of 18.5 and above, that is equivalent to Aa2/AA (see Table 2), and the average SBYs was about $4 \%$. In 2011, when the average SCRs in ordinal scale dropped below $18.5 \%$ or Aa3/AA-, the average $S B Y$ s should have increased above $4 \%$ to compensate for the additional risk. 
Table 6. Significance and sign of granular SCRs coefficients on SBYS

\begin{tabular}{llcccccccccc}
\hline & 2008 & 2009 & 2010 & 2011 & 2012 & 2013 & 2014 & 2015 & 2016 & 2017 \\
\hline Moody's & Significant & N/A & Yes & No & No & No & No & No & No & No & Yes \\
SCRs & Sign & & + & + & + & + & + & - & + & + & - \\
\cline { 2 - 9 } S\&P & Significant & No & Yes & No & No & No & No & No & No & Yes & Yes \\
SCRs & Sign & - & + & - & - & + & - & - & - & + & - \\
\cline { 2 - 9 } & Significant & No & No & No & No & No & No & Yes & No & Yes & No \\
SCRs & Sign & - & + & - & + & - & - & - & + & + & - \\
\hline
\end{tabular}

Note: The row labelled as 'Significant' refers to whether the estimated coefficients are significant, where Yes denotes significance at $5 \%$ level, and No denotes not significant. The Sign denotes the positive and negative signs of the estimated coefficients. The referenced results are from Table 5.

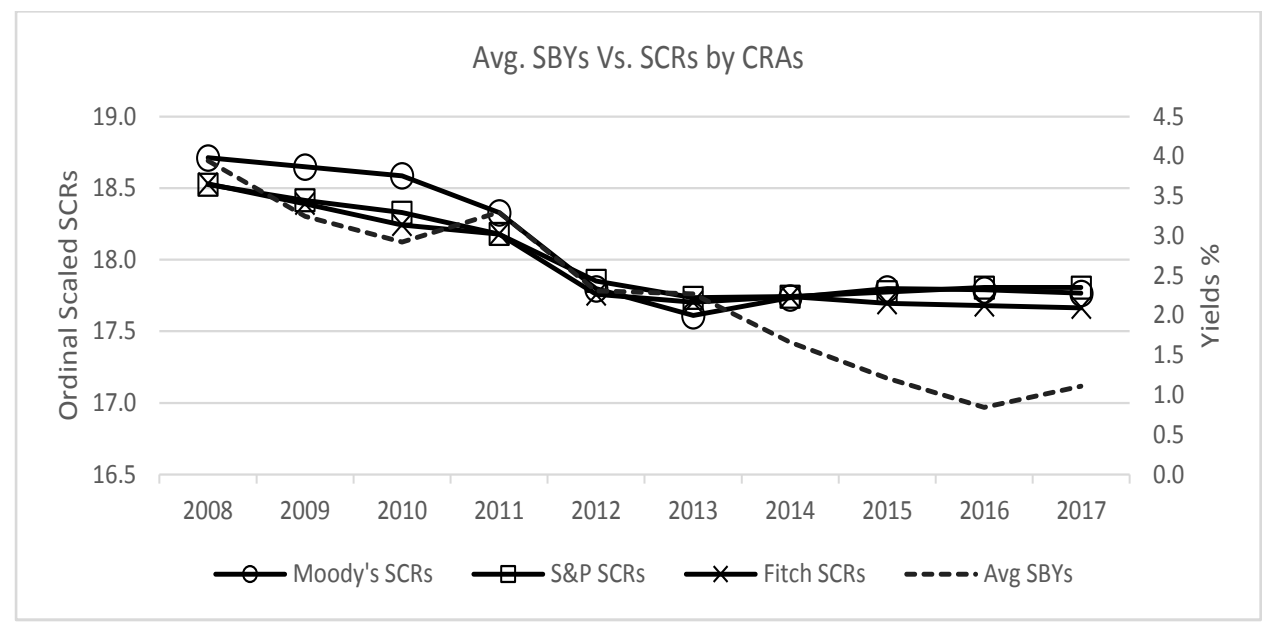

Figure 1. Average SBYs vs SCRs by Moody's, S\&P and Fitch from Q1 2008 to Q4 2017

Note: The average $S B Y_{S}$ is derived using simple arithmetic method of averaging from Q1 to Q4 data points for each year across the 32 countries. The ordinal scaled SCRs issued by respective CRAs are converted into average SCRs by CRAs and year.

In reality, the average SBYS was treading below $4 \%$, at about $3.25 \%$. In the following year, the average SCRs issued by all three CRAs dropped below the ordinal scale of 18 but stayed above 17.5, this means the average risk profile of the sample had worsened further from Aa3/AA- towards A1/A+. The average $S B Y S$ contracted further from $3.25 \%$ in 2011 to about $2.25 \%$ in 2012, and dropped below 1\% in 2016 while the average risk profile of the sample had worsened. The disassociation between average SCRs and average $S B Y$ s is consistent with the granular estimates. What caused the average $S B Y S$ of the sample of 32 countries to drop from $4 \%$ in 2008 to about $1 \%$ in 2017 was also the cause that rendered SCRs informational value irrelevant. We conjectured that ZBPR and QEP had such capacity and influence over the sample of 32 countries. 
Regarding SCRs informational value on SCDSSS price discovery, the empirical results derived from the full sample is rather surprising. This is because SCDSSs are the derivative instruments of $S B Y S$, the reference entity. On that basis, if SCRs informational value are found irrelevant on SBYS, the same should be expected on SCDSSs. Apparently, the empirical results indicate that is not true. The SCRs informational value was relevant on SCDSSs price discovery when ZBPR and QEP were in effect.

To scrutinise further, the significance and sign of granular estimates of SCRs on SCDSSs are summarised in Table 7. It is easy to spot from the table that only in $\mathbf{2 0 1 0}$ and 2014, SCRs issued by all three CRAs were significant at 5\% level and with the expected negative sign in explaining SCDSSs. In year 2011, only SCRs issued by Moody's were significant and with the negative sign as expected. In the remaining 7 years, the SCRs, irrespective of CRAs, were irrelevant on SCDSSs price discovery.

Table 7. Significance and sign of granular SCRs coefficients on SCDSSs

\begin{tabular}{|c|c|c|c|c|c|c|c|c|c|c|c|}
\hline & & 2008 & 2009 & 2010 & 2011 & 2012 & 2013 & 2014 & 2015 & 2016 & 2017 \\
\hline Moody's & Significant & No & No & Yes & Yes & No & No & Yes & No & No & No \\
\hline SCRs & Sign & + & + & - & - & + & + & - & + & + & - \\
\hline$S \& P$ & Significant & No & No & Yes & No & No & Yes & Yes & No & No & No \\
\hline SCRs & Sign & + & + & - & - & + & + & - & - & - & + \\
\hline Fitch & Significant & No & No & Yes & No & No & Yes & Yes & No & No & No \\
\hline SCRs & Sign & + & + & - & - & + & + & - & - & + & + \\
\hline
\end{tabular}

Note: The row labelled as 'Significant' refers to whether the estimated coefficients are significant, where Yes denotes significance at $5 \%$ level, and No denotes not significant. The Sign denotes the positive and negative signs of the estimated coefficients. The referenced results are from Table 5.

When the significance and sign of granular estimates and the line chart depicted in Figure 2 are analysed together, it becomes easier to comprehend why only granular estimates in year 2010, 2011 and 2012 are significant at 5\% level and with the expected negative sign. Prior to 2010, the average SCRs of S\&P and Fitch had dropped below 18.5 but the average SCRs of Moody's was still above the 18.5. Only in year 2010, the average SCRs of Moody's edged towards 18.5 and the average SCRs of S\&P and Fitch also worsened further. In the following year, the average SCRs of S\&P and Fitch were relatively the same as 2010, but the average SCRs of Moody's dropped steeply and crossed below 18.5 for the first time. The average SCDSSs responded with increased in spreads from 80 basis points (bps) to 100bps in 2009, and jumped to 160bps in 2011. However, from 2012 onwards the average SCDSSs appeared to follow the average SBYS downward trajectory trend by disregarding the SCRs informational value on worsening credit profile of the sample. The average SCDSSs contracted from 160bps in 2011 to $60 \mathrm{bps}$ in 2014, which coincided with the granular estimates of 2014 where SCRs issued by all three CRAs are significant and with the expected negative sign. The 2014 results suggest that the financial market would have resisted the pull factor of ZBPR and QEP to keep the average SCDSSs at 60bps from 2014 to 2016 as contingency against the 


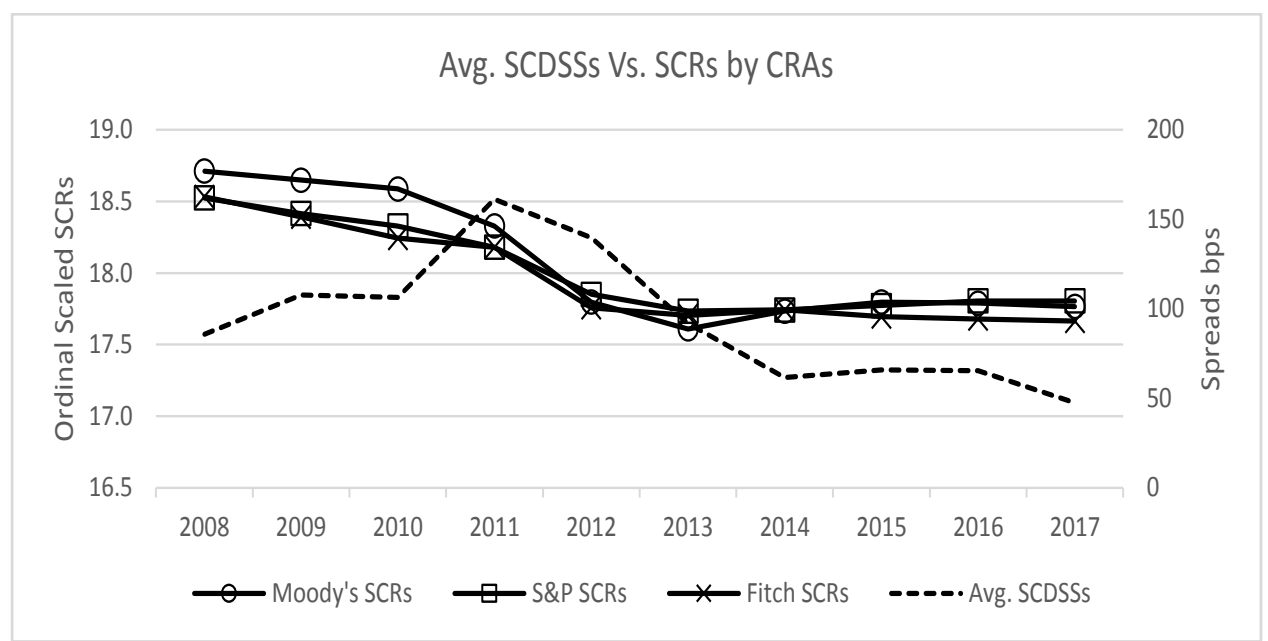

Figure 2. Average SCDSSs vs. SCRs by Moody's, S\&P and Fitch from Q12008 to Q42017

Note: The average SCDSSs is derived using simple arithmetic method of averaging from Q1 to Q4 data points for each year across 32 countries. The ordinal scaled SCRs issued by respective CRAs are converted into average SCRs by CRAs and year.

worsened risk profile. However, the line of defence did not last, the average SCDSSS dropped below 60bps to 50bps in 2017. This is probably why the strength of the coefficients estimated from the full sample are significantly lower at a range of -0.031 to -0.052 as compared to granular coefficients from 2010 at the range of -0.156 to -0.359 , or 2014 at the range of -0.169 to -0.188 . The cross analysis between estimates from full sample and annual datasets revealed that the SCRs informational value on SCDSSs price discovery was also affected by ZBPR and QEP. The effect rendered SCRs informational value irrelevant was only apparent from 2012 onwards.

\section{Conclusion}

Given the importance of SCRs as proxies of rated countries' creditworthiness and the SCRs informational value on debts price discovery, this study examines the potential effect of ZBPR and QEP on SCRs informational value for SBYS and SCDSS price discoveries.

The empirical results of this paper proved that the SCRs informational value on SBYS and SCDSSs price discoveries were indeed disregarded and rendered irrelevant when ZBPR and QEP were in effect. The granular estimates show that the SCRs informational value was disregarded on SBYS since 2008 and on SCDSSs price discovery since 2012.

In conclusion, the findings of this preliminary study provide clear evidence that SCRs informational value was indeed rendered irrelevant on SBYS and SCDSSS pricing when ZBPR and QEP were in effect. The findings of this study should caution about the reliability of $S B Y S$ as reference of risk free rate and the SCDSSS as reference of credit risk premium in many empirical studies. 


\section{References}

Afonso, A. (2003). Understanding the determinants of sovereign debt ratings: Evidence for the two leading agencies. Journal of Economics and Finance, 27(1), 56-74. https://doi.org/ 10.1007/BF02751590

Afonso, A., Arghyrou, M., \& Kontonikas, A. (2013). The determinants of sovereign bond yield spreads in the EMU (ISEG Economics Working Paper No. 36/2012/DE/UECE). https://doi. org/10.2139/ssrn.2223140

Afonso, A., Gomes, P., \& Rother, P. (2009). Ordered response models for sovereign debt ratings. Applied Economics Letters, 16(8), 769-773. https://doi.org/10.1080/13504850701221931

Afonso, A., Gomes, P., \& Rother, P. (2011). Short- and long-run determinants of sovereign debt credit ratings. International Journal of Finance \& Economics, 16(1), 1-15. https://doi.org/ $10.1002 /$ ijfe. 416

Alsakka, R., \& Gwilym, O. (2010a). Leads and lags in sovereign credit ratings. Journal of Banking and Finance, 34(11), 2614-2626. https://doi.org/10.1016/j.jbankfin.2010.05.001

Alsakka, R., \& Gwilym, O. (2010b). Split sovereign ratings and rating migrations in emerging economies. Emerging Markets Review, 11(2), 79-97. https://doi.org/10.1016/j.ememar. 2009.11.005

Badaoui, S., Cathcart, L., \& El-Jahel, L. (2013). Do sovereign credit default swaps represent a clean measure of sovereign default risk? A factor model approach. Journal of Banking and Finance, 37(7), 2392-2407. https://doi.org/10.1016/j.jbankfin.2013.01.038

Beber, A., Brandt, M.W., \& Kavajecz, K.A. (2009). Flight-to-quality or flight-to-liquidity? Evidence from the Euro-Area bond market. The Review of Financial Studies, 22(3), 925-957. https:// doi.org/10.1093/rfs/hhm088

Bissoondoyal-Bheenick, E. (2005). An analysis of the determinants of sovereign ratings. Global Finance Journal, 15(3), 251-280. https://doi.org/10.1016/j.gfj.2004.03.004

Cantor, R., \& Packer, F. (1994). The credit rating industry. FRBNY Quarterly Review, 19(2), 1-26. https://www.newyorkfed.org/medialibrary/media/research/quarterly_review/1994v19/ v19n2article1.pdf

Cantor, R., \& Packer, F. (1995). Sovereign credit ratings. Current Issues in Economics and Finance, 1(3), 1-6. https://www.newyorkfed.org/medialibrary/media/research/current_issues/ci1-3. pdf

Cantor, R., \& Packer, F. (1996). Determinants and impact of sovereign credit ratings. FRBNY Economic Policy Review, 2(2), 37-53. https://www.newyorkfed.org/medialibrary/media/ research/epr/96v02n2/9610cant.pdf

Cantor, R., Packer, F., \& Cole, K. (1997). Split ratings and the pricing of credit risk. Journal of Fixed Income, 7(3), 72-82. https://doi.org/10.3905/jfi.1997.408217

Canuto, O., Santos, P.F.P.D., \& Porto, P.C.D.S. (2012). Macroeconomics and sovereign risk ratings. Journal of International Commerce, Economics and Policy, 3(2), 1-25. https://doi.org/ 10.1142/S1793993312500111

Culp, C.L., Merwe, A.v.d., \& Stärkle, B.J. (2016). Single-name credit default swaps: A review of the empirical academic literature. https://www.isda.org/a/KSiDE/single-name-cds-literaturereview-culp-van-der-merwe-staerkle-isda.pdf

Ederington, L.H. (1986). Why split ratings occur. Financial Management, 15(1), 37-47. https:// www.jstor.org/stable/3665276

Ederington, L.H., Yawitz, J.B., \& Roberts, B.E. (1987). The informational content of bond ratings. The Journal of Financial Research, 10(3), 211-226. https://doi.org/10.1111/j.1475-6803.1987. tb00492.x

Fama, E.F. (1969). Efficient capital markets: A review of theory and empirical work. The Journal of Finance, 25(2), 383-417. https://doi.org/10.2307/2325486 
Friedman, T.L. (1995, February 22). Foreign affairs; Don't mess with Moody's. The New York Times, p. 19. https://www.nytimes.com/1995/02/22/opinion/foreign-affairs-don-t-mess-withmoody-s.html

Hill, P., Brooks, R., \& Faff, R. (2010). Variations in sovereign credit quality assessments across rating agencies. Journal of Banking and Finance, 34(6), 1327-1343. https://doi.org/10.1016/j. jbankfin.2009.11.028

Hull, J.C., \& White, A.D. (2000). Valuing credit default swaps I: No counterparty default risk. The Journal of Derivaties, 8(1), 29-40. https://doi.org/10.3905/jod.2000.319115

Jaramillo, L., \& Tejada, C.M. (2011). Sovereign credit ratings and spreads in emerging markets: Does investment grade matter? (IMF Working Paper WP/11/44). https://www.imf.org/en/ Publications/WP/Issues/2016/12/31/Sovereign-Credit-Ratings-and-Spreads-in-EmergingMarkets-Does-Investment-Grade-Matter-24677

Jaramillo, L., \& Weber, A. (2013). Bond yields in emerging economies: It matters what state you are in. Emerging Markets Review, 17(December), 169-185. https://doi.org/10.1016/j. ememar.2013.09.003

Longstaff, F.A., Pan, J., Pedersen, L.H., \& Singleton, K.J. (2011). How sovereign is sovereign credit risk? American Economic Journal: Macroeconomics, 3(2), 75-103. http://pages.stern.nyu. edu/ /pederse/papers/SovereignLPPS.pdf

Mellios, C., \& Paget-Blanc, E. (2006). Which factors determine sovereign credit ratings? The European Journal of Finance, 12(4), 361-377. https://doi.org/10.1080/13518470500377406

Miricescu, E-C. (2015). The correlation of sovereign rating and bonds' interest rate in EU member states. Transy/vanian Review of Administrative Sciences, 45(E/2015), 136-148. https://www. rtsa.ro/tras/index.php/tras/article/download/442/431

Reusens, P., \& Croux, C. (2017). Sovereign credit rating determinants: A comparison before and after the European debt crisis. Journal of Banking and Finance, 77(April), 108-121. https:// doi.org/10.1016/j.jbankfin.2017.01.006

Rowland, P. (2004). Determinants of spread, credit ratings and creditworthiness for emerging market sovereign debt: A follow-up study using pooled data analysis. Banco de la Replublica de Colombia, Borradores de Economia, 1-37. https://repositorio.banrep.gov.co/bitstream/ handle/20.500.12134/5314/be_296.pdf

Sy, A.N.R. (2002). Emerging market bond spreads and sovereign credit ratings: Reconciling market views with economic fundamentals. Emerging Market Review, 3(4), 380-408. https://doi. org/10.1016/S1566-0141(02)00043-2

Wooldridge, J.M. (2002). Econometric analysis of cross section and panel data. Cambridge, MIT Press. https://jrvargas.files.wordpress.com/2011/01/wooldridge_j-_2002_econometric_ analysis_of_cross_section_and_panel_data.pdf 
